\title{
ANALISIS PRESTASI BELAJAR MATEMATIKA DITINJAU DARI KEMAMPUAN BERPIKIR KRITIK DAN KONSEP DIRI SISWA
}

\author{
Dona Katarina \\ Program Studi Informatika, Universitas Indraprasta PGRI \\ Email: dona.katrin@gmail.com
}

\begin{abstract}
Abstrak
Penelitian ini bertujuan mengetahui seberapa besar pengaruh prestasi belajar matematika dapat meningkat ditinjau dari kemampuan berpikir kritik dan konsep diri Siswa. Subjek penelitian adalah Siswa SMPN 34, 23 dan 42 di daerah Pademangan Jakarta Utara. Sampel sebanyak 90 orang dengan masing-masing sampel tiap sekolah sebanyak 30 orang. Hasil penelitian menunjukkan (1).terdapat pengaruh langsung yang signifikan kemampuan berpikir kritik dan konsep diri terhadap prestasi belajar matematika Siswa dimana besarnya pengaruh kemampuan berpikir kritik terhadap prestasi belajar (2).terdapat pengaruh yang signifikan konsep diri terhadap prestasi belajar dimana besarnya pengaruh konsep diri terhadap prestasi belajar. (3).terdapat pengaruh langsung kemampuan berpikir kritik terhadap konsep diri siswa dimana besarnya pengaruh kemampuan berpikir kritik terhadap konsep diri. Implikasi dalam penelitian ini mencakup: (1). Semakin baik kemampuan berpikir kritik siswa maka semakin tinggi pula prestasi belajar yang dicapai dalam pelajaran matematika. (2). Semakin baik konsep diri yang dimiliki siswa dalam pelajaran matematika maka akan semakin baik pula prestasi yang diperoleh. (3). Lingkungan yang baik, didikan guru dan orangtua yang dapat membuat anak semakin percaya diri dan berkemampuan berpikir kritik merupakan bentuk dari motivasi yang bertujuan untuk peningkatan prestasi belajar matematika.
\end{abstract}

Kata Kunci : Kemampuan Berpikir Kritik, Konsep Diri, Prestasi Belajar Matematika Siswa

\begin{abstract}
This study aims to determine how much influence mathematics learning achievement can be increased in terms of students' critical thinking and self-concept. The subjects of the study were Junior High School Students 3423 and 42 in Pademangan, North Jakarta. The number of samples of 90 people with each sample of each school as many as 30 people. Data analysis using descriptive statistics method and test technique requirement of data analysis. The results showed (1). there is a significant direct influence of the ability of critical thinking and self-concept to the achievement of learning mathematics Students where the magnitude of the influence of the ability to think criticism of learning achievement are, (2). There is a significant influence of self-concept on learning achievement where the influence of self concept to learning achievement, (3). The direct influence of critical thinking ability on student self concept where the influence of critical thinking ability to self concept. (1). The better the students' critical thinking skills the higher the learning achievement achieved in the mathematics lesson. (2). The better the student's self concept in the math lesson the better the achievement. (3). A good environment, educated teachers and parents who can make children more confident and able to think critically is a form of motivation that aims to improve mathematics learning achievement.
\end{abstract}

Keywords: Critical Thinking Ability, Self Concept, Student Achievement Learning Mathematics

\section{PENDAHULUAN}

Pendidikan dan pengajaran adalah suatu proses yang sadar tujuan. Tujuan dapat diartikan sebagai suatu usaha untuk memberikan rumusan hasil yang diharapkan siswa setelah melaksanakan pengalaman belajar [1]. Tercapai tidaknya tujuan pengajaran salah satunya adalah terlihat dari prestasi belajar yang diraih siswa. Dengan prestasi yang tinggi, para siswa mempunyai indikasi berpengetahuan yang baik.

Salah satu faktor yang mempengaruhi prestasi belajar siswa adalah kemampuan berpikir kritik dan konsep diri yang 
dimiliki oleh masing-masing siswa. Kemampuan berpikir kritik adalah Kemampuan mengenal diri atau mengkonsep diri dan berpikir secara kritik sangatlah dibutuhkan dalam mengembangkan kemampuan menganalisis, memecahkan masalah, mensintesis serta menyimpulkan permasalahan yang dihadapi dalam kehidupan sehari-hari, menguji atau mengkritisi untuk memperoleh jawaban atas permasalahan yang dihadapinya. Kemampuan dasar inilah sangat dibutuhkan dalam meningkatkan prestasi hasil belajar khususnya dibidang Matematika. Peserta didik yang memiliki kemampuan berpikir kritis tentu akan terhindar dari ketidakmampuan dan keraguan mengambil keputusan [2].

Adapun tujuan pengajaran matematika disekolah berdasarkan standar kurikulum yang berbasis kompetensi agar siswa memperoleh kemampuan berhitung dan berpikir logis, kritis dan sistematis dalam memahami suatu konsep khususnya tentang matematika, dengan adanya pengajaran matematika, siswa mampu mengembangkan kompetensi cara berpikir mengenai pemahaman wawasan materi matematika dan dapat diterapkan di kehidupan bermasyarakat. Menurut Haryono "kesadaran berpikir logis yang tampil pada diri seseorang atau masyarakat adalah refleksi dari wawasannya."

Terkait kemampuan penguasaan materi peserta didik, ada faktor yang tentunya mempengaruhi peserta didik untuk mempelajari lebih dalam mengenai matematika. Adapun faktor tersebut adalah kemampuan berpikir kritik dan konsep diri siswa. Kemampuan berpikir kritik siswa tertuju pada sejauhmana siswa dapat menganalisa,mengidentifikasi,membandingkan menguji berbagai informasi alih menyimpulkan sedangkan untuk konsep diri tertuju pada rasa percaya diri dan harga diri dalam mengerjakan berbagai bentuk soal khususnya matematika. Maka dengan ini tujuan penelitian ini bertujuan mengetahui seberapa besar pengaruh prestasi belajar matematika dapat meningkat ditinjau dari kemampuan berpikir kritik dan konsep diri Siswa.

Prestasi Belajar adalah suatu nilai yang menunjukkan hasil yang tertinggi dalam belajar yang ingin dicapai menurut kemampuan siswa dalam mengerjakan sesuatu pada saat tertentu. Prestasi belajar siswa ditentukan oleh dua faktor yaitu intern dan ekstern. Faktor intern merupakan faktor-faktor yang berasal atau bersumber dari siswa itu sendiri, sedangkan faktor eksternal merupakan faktor yang berasal atau bersumber dari luar peserta didik.

Menurut para ahli (Suwangsih \& Tiurlina, 2010), matematika berasal dari bahasa latin "mathematika" yang mulanya diambil dari bahasa yunani "Mathematike" yang berarti mempelajari. Perkataan itu mempunyai asal kata mathema yang berarti pengetahuan atau ilmu. Kata mathematike berhubungan pula dengan kata lainnya yang hampir sama yaitu mathein atau mathenein yang artinya belajar. Jadi berdasarkan asal katanya maka matematika berarti ilmu pengetahuan yang didapat dengan berpikir. Adapun tujuan pengajaran matematika disekolah adalah : agar siswa mampu memiliki pengetahuan berpikir logis untuk memahami dan menjelaskan proses dalam kehidupan dimasyarakat serta menemukan dan menumbuhkan jati diri bangsa ditengah-tengah masyarakat dunia.

Konsep diri terbentuk melalui proses belajar sejak masa pertumbuhan seorang manusia dari kecil hingga dewasa. Sedangkan harga diri timbul dari penilaian seseorang akan diri dan lingkungan pun memberikan pengaruh terhadap diri. Lingkungan, pengalaman dan pola asuh orang tua turut memberikan pengaruh yang 
signifikan terhadap konsep diri dan harga diri yang akan terbentuk.

Kemampuan berpikir kritik pada setiap individu harus berasal dari pemikiran yang masuk akal dan efektif yang terfokus untuk memusatkan apa yang mesti dipercaya atau dilakukan [3]. Berikut merupakan keterampilan-keterampilan berpikir yang dipandang sebagai landasan untuk berpikir kritis diantaranya: (1) Mengenal masalah, (2) Menemukan cara-cara yang dapat dipakai untuk menangani masalah-masalah yang diahadapi, (4) Mengumpulkan dan menyusun informasi yang diperlukan., (5) Mengenal Asumsi-asumsi dan nilai-nilai yang tidak dinyatakan, (6) Memahami dan menggunakan bahasa yang tepat, jelas, dan khas, (7) Menganalisis data, (8) Menilai fakta dang mengevaluasi pertanyaanpertanyaan, (9) Mengenal adanya hubungan yang logis antara masalahmasalah, (10) Menarik kesimpulankesimpulan dan kesamaan-kesamaan yang diperlukan.

Berdasarkan uraian tersebut dapat disimpulkan bahwa kemampuan berpikir kritik merupakan proses intelektual yang dengan aktif dan terampil mengkonseptualisasi, menerapkan, menganalisis, mensintesis dan mengevaluasi informasi yang dikumpulkan atau dihasilkan dari pengamatan, pengalaman, refleksi, penalaran, atau komunikasi untuk memandu keyakinan dan tindakan.

Orang yang memiliki kemampuan berpikir kritis, dapat mengajukan pertanyaan dengan tepat, mencari dan menggunakan informasi yang relevan, memilah-milah informasi, mengajukan alasan yang logis berdasarkan informasi dan mengambil kesimpulan yang dapat dipercaya, meyakinkan terhadap suatu persoalan (Tim Pusat Studi Pancasila UGM dalam Buku Membangun Kedaulatan Bangsa berdasarkan Nilai-nilai Pancasila: Pemberdayaan Masyarakat Dalam Kawasan Terluar, Terdepan dan Tertinggal (3T) [4].

\section{METODE}

Penelitian dilakukan selama kurang lebih 4 bulan dari bulan Maret sampai Juni 2015, dengan mengambil sampel sebanyak 90 sampel secara random. Sampel adalah bagian dari populasi yang diambil hanya sebagian atau mewakili dari populasi yang diteliti [5]. Lebih lanjut penelitian ini menggunakan metode survei, pemberian kuesioner dan melakukan tes berupa pemberian soal soal matematika terhadap siswa-siswa di kelas VII SMP Negeri 42, SMP Negeri 34 dan SMP Negeri 23 sekecamatan Pademangan, Jakarta Utara. Perlakuan terhadap variabel-variabel yang diteliti yaitu kemampuan berpikir kritis (X1) dan konsep diri (X2) terhadap hasil belajar matematika $(\mathrm{Y})$.

Metode yang digunakan dalam penelitian mencakup Analisis Deskriptif Variabel dan Teknik Pengujian Persyaratan Analisis Data yang terdiri dari uji normalitas, uji linearitas dan uji kolinearitas terhadap variabel kemampuan berpikir kritis (X1), Konsep diri (X2) dan Prestasi Belajar (Y) dengan program SPSS 21.0. Perhitungan penelitian juga menggunakan aplikasi SPSS 21.0 dengan metode analisis jalur (path_analysis). 


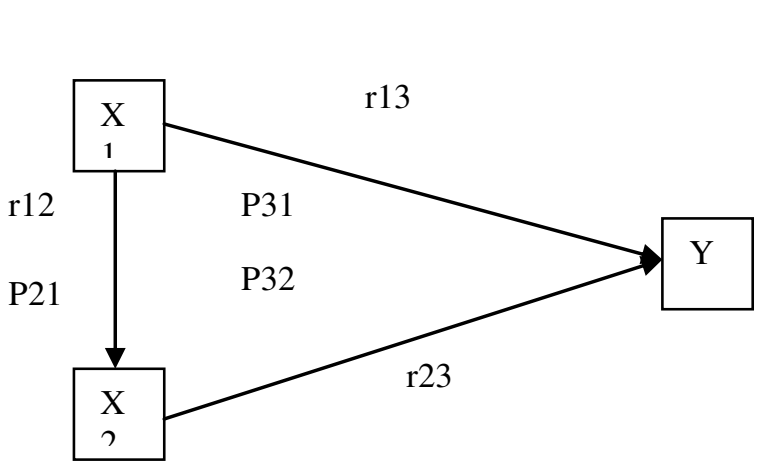

Keterangan

X1 Kemampuan berpikir kritik

$\mathrm{X} 2$ Konsep diri

Y Prestasi belajar Matematika

r12 Koefisien Korelasi Variabel X1 terhadap X2

P32 Koefisien Jalur Variabel X2 terhadap

P21 Koefisien Jalur X1 terhadap Y

r13 Koefisien Korleasi Variabel X1 terhadap Y

P31 Koefisien Jalur Variabel X1 terhadap Y

r23 Koefisien Korelasi Variabel X2 terhadap Y

\section{Gambar 1. Hubungan Kemampuan berpikir kritik dan konsep diri terhadap prestasi} belajar matematika (Konstelasi Masukan).

HASIL DAN PEMBAHASAN

Berdasarkan hasil pengolahan data gambaran statistik analisis deskriptif masing - masing variabel dari hasil perhitungan dan pengujian yang dilakukan dengan program aplikasi SPSS 21.0, sebagai berikut:

Tabel 1. Deskriptif Data Penelitian

\begin{tabular}{|c|c|c|c|c|}
\hline & & Kemampuan berpikir kritis & Konsep Diri & Prestasi Belajar Matematika \\
\hline \multirow{2}{*}{$\mathrm{N}$} & Valid & 90 & 90 & 90 \\
\hline & Missing & 0 & 0 & 0 \\
\hline Mean & & 49.78 & 111.14 & 63.71 \\
\hline Std. Error Of mean & & .553 & .569 & 1.189 \\
\hline Median & & 50.00 & 112.00 & 64.00 \\
\hline Mode & & 50 & 115 & 64 \\
\hline Std. Deviation & & 5.244 & 5.402 & 11.29 \\
\hline Variance & & 27.501 & 29.181 & 127.219 \\
\hline Range & & 26 & 27 & 51 \\
\hline Minimum & & 34 & 98 & 35 \\
\hline Maximum & & 60 & 125 & 86 \\
\hline Sum & & 4480 & 10003 & 5734 \\
\hline
\end{tabular}

Dari deskripsi data statistik penelitian pada tabel 1 terlihat antara nilai rata-rata untuk variabel prestasi belajar, kemampuan berpikir kritis dan konsep diri hampir sama dengan nilai masing-masing mediannya yaitu 63.71 dan 64 untuk prestasi belajar, 49.78 dan 50 untuk variabel kemampuan berpikir kritis serta 111.14 dan 112 untuk variabel konsep diri Hal ini menunjukkan bahwa data antara variabel kemampuan berpikir kritis dan konsep diri cukup representative dan berpengaruh secara signifikan terhadap variabel prestasi belajar matematika. Untuk Pengujian persyaratan analisis data peneliti melakukan pengujian dengan uji normalitas, uji linearitas dan uji multikolinearitas atau kolinearitas antara variabel bebas kemampuan berpikir kritik (X1), Konsep diri (X2) terhadap variabel prestasi belajar $(\mathrm{Y})$ dan berdasarkan hasil pengujian dengan program aplikasi SPSS 21,0 menunjukkan bahwa data berdistribusi normal, liner dan bebas dari adanya kolinearitas antara variabel kemampuan berpikir kritik (X1) dan Konsep diri (X2).

Untuk pengujian normalitas variabel dilakukan dengan menggunakan program aplikasi SPSS 21.0 dengan menggunakan metode Kolmogorov - Smirnov. Kriteria dari normalitas data "jika $p$ value (sig)> 0.05 maka H0 diterima maka data 
berdistribusi normal sedangkan jika $\mathrm{p}$ value (sig $)<0.05$ maka $\mathrm{H} 0$ ditolak, data tidak berdistribusi normal. Adapun hasil perhitungan variabel $p$ value (sig) untuk variabel kemampuan berpikir kritik sebesar $0.321, p$ value(sig) konsep diri sebesar 0.385 dan $p$ value (sig) prestasi belajar sebesar 0.662 .

Sedangkan untuk uji linearitas dimaksud untuk melihat bentuk persamaan regresi yang terbentuk dari variabel bebas terhadap variabel terikat yakni X1 terhadap $\mathrm{Y}, \mathrm{X} 2$ terhadap $\mathrm{Y}$ dan $\mathrm{X} 1$ terhadap X2. Hasil uji linearitas dengan program aplikasi SPSS 21.0 didapat nilai variabel X1 terhadap Y dan X2 terhadap Y adalah Linear hal ini dibuktikan dengan nilai Sig Deviation from Linearity pada X1 terhadap $\mathrm{Y}=0.616$, nilai Sig Deviation from Linearity X2 terhadap Y $=0.059$, dan Sig Deviation from Linearity pada X1 terhadap $\mathrm{X} 2=0.627$ lebih besar dari 0.05 . Sedangkan untuk uji kolinearitas variabel kemampuan berpikir kritik (X1) dan konsep diri (X2) berdasarkan perhitungan aplikas SPSS 21.0 di peroleh nilai
Tolerance 0.950 masih dibawah angka 1 (satu) dan angka VIF 1.053 mendekati angka 1 (satu) maka disimpulkan terdapat dugaan bebas dari adanya kolinearitas antara variabel kemampuan berpikir kritik dan konsep diri.

Penelitian ini bertujuan untuk mengetahui seberapa besar pengaruh prestasi belajar dapat meningkat ditinjau dari kemampuan berpikir kritik dan konsep diri. Adapun untuk pengujian keterhubungan antar variabel penelitian, peneliti menggunakan pengujian koefisien korelasi dan path analysis antara variabel kemampuan berpikir kritik (X1), variabel konsep diri (X2) dan prestasi belajar (Y), Hasil perhitungan dilakukan dengan menggunakan aplikasi SPSS 21,0. Berikut hasil perhitungan pengujian koefisien korelasi dapat dilihat pada tabel 2 dan tabel 3 merupakan hasil pengujian hipotesis dengan analisis jalur untuk variabel kemampuan berpikir kritik (X1), Variabel konsep diri (X2) terhadap variabel prestasi belajar (Y).

\section{Tabel 2. Hasil perhitungan koefisien korelasi}

\begin{tabular}{ccc}
\hline Hubungan Antar Variabel $\mathbf{r}_{\mathbf{i j}}$ & Korelasi & Nilai \\
\hline Kemampuan berpikir kritik $\left(\mathrm{X}_{1}\right)$ dengan Prestasi Belajar & $\mathrm{r}_{13}$ & 0.709 \\
Konsep Diri $\left(\mathrm{X}_{2}\right)$ dengan Prestasi Belajar $\left(\mathrm{X}_{3}\right)$ & $\mathrm{r}_{23}$ & 0.384 \\
Kemampuan Berpikir Kritik $\left(\mathrm{X}_{1}\right)$ dengan Konsep Diri $\left(\mathrm{X}_{2}\right)$ & $\mathrm{r}_{12}$ & 0.224 \\
\hline
\end{tabular}

Dari tabel 2. menunjukkan bahwa nilai variabel kemampuan berpikir kritik (X1), variabel konsep diri dan variabel prestasi belajar berkorelasi, dimana nilai p21 = $0.224, \mathrm{p} 31=0.656$ dan $\mathrm{p} 32=0.237$ dimana kriteria penilaian koefisien korelasi jika nilai koefisien korelasi ketiga variabel tersebut lebih besar dari $>0.05$ maka diagram alur yang disusun diterima dan jika lebih kecil dari $<0.05$ maka koefisien korelasi yang disusun ditolak. Adapun untuk kriteria pengujian dengan analisis jalur (path analysis), jika $\mathrm{t}_{\text {hitung }}>\mathrm{t}_{\text {tabel }}$ maka $\mathrm{H} 0$ diterima dan Jika $\mathrm{t}_{\text {hitung }}<\mathrm{t}_{\text {tabel }}$ maka H1 diterima. 
Tabel 3. Signifikansi Hasil Perhitungan Koefisien Jalur Kemampuan Berpikir Kritik (X1),Konsep Diri (X2) terhadap Prestasi Belajar Matematika (Y) dan Kemampuan berpikir Kritik (X1) terhadap Konsep Diri (X2)

\begin{tabular}{|c|c|c|c|c|c|c|}
\hline \multicolumn{2}{|c|}{ Model } & \multicolumn{2}{|c|}{ Unstandardized Coefficients } & \multirow{2}{*}{$\begin{array}{l}\text { Standardized } \\
\text { Coefficients } \\
\text { Beta }\end{array}$} & \multirow[t]{2}{*}{$\mathbf{t}$} & \multirow[t]{2}{*}{ Sig } \\
\hline & & $B$ & Std.Error & & & \\
\hline \multirow[t]{9}{*}{1} & (Constant) & -61.496 & 17.082 & & -3.600 & .001 \\
\hline & Kemampuan & 1.411 & .158 & .656 & 8.947 & .000 \\
\hline & a Berpikir & & & & & \\
\hline & Kritik & & & & & \\
\hline & Konsep Diri & .495 & .153 & .237 & 3.232 & .002 \\
\hline & (Constant) & 99.656 & 5.356 & & 18.606 & .000 \\
\hline & Kemampuan & .231 & .107 & .224 & 2.157 & .034 \\
\hline & b Berpikir & & & & & \\
\hline & Kritik & & & & & \\
\hline
\end{tabular}

Dari hasil perhitungan tabel 3. dengan bantuan aplikasi SPSS versi 21.0 ternyata ada hubungan secara langsung kemampuan berpikir kritik dengan prestasi belajar. Ini terlihat dari $t_{\text {hitung dimana variabel }}$ kemampuan berpikir kritik dan konsep diri terhadap prestasi belajar lebih besar dari $\mathrm{t}_{\text {tabel, }} \mathrm{t}_{\text {hitung }}=8.947>\mathrm{t}_{\text {tabel }}=1.987$ dengan taraf signifikan $5 \%$ atau $a=0.05$, sehingga membuktikan bahwa terdapat pengaruh langsung kemampuan berpikir kritik terhadap hasil prestasi belajar matematika siswa.

Besarnya pengaruh kemampuan berpikir kritik terhadap prestasi belajar adalah : KD $=\mathrm{p}_{31}{ }^{2} \times 100 \%=0.656^{2} \times 100 \%=$ $43.03 \%$, sisanya sebesar $56.97 \%$ dipengaruhi oleh faktor-faktor lain diluar kemampuan berpikir kritik.

Menurut Slameto, banyak faktor yang mempengaruhi keberhasilan (prestasi) belajar. Diantaranya faktor psikologis, inteligensi yang memainkan peranan yang besar terhadap prestasi belajar [6]. Oleh sebab itu perlu menjadi perhatian bagi para pendidik atau tenaga kependidikan agar perlu adanya peningkatan pembelajaran yang menggunakan kemampuan penganalisisan dan pengevaluasian atau pengujian kebenaran atas permasalahan yang dihadapi berupa kesimpulan antara teori dengan kenyataan terhadap permasalah yang dihadapi pada pembelajaran sehingga membuat peserta didik dapat mengembangkan kemampuan berlogika atau kemampuan berpikir kritik dalam pembelajaran.

Dari hasil perhitungan tabel 3 dapat dilihat juga adanya hubungan secara langsung konsep diri dengan prestasi belajar. Ini terlihat dari $\mathrm{t}_{\text {hitung }}>\mathrm{t}_{\text {tabel }}=3.232>1.987$ dengan taraf signifikan $5 \%$ atau $a=0.05$, sehingga membuktikan bahwa konsep diri secara langsung mempengaruhi peningkatan prestasi belajar matematika.

Besarnya pengaruh konsep diri terhadap prestasi belajar adalah : $\mathrm{KD}=\mathrm{p}_{23}{ }^{2} \mathrm{X} 100$ $\%=0.237^{2} \times 100 \%=0.056 \times 100 \%,=$ $5.61 \%$ dan sisanya sebesar $94 \%$ dipengaruhi oleh faktor-faktor lain diluar konsep diri.

Berdasarkan hasil uji penelitian survey yang telah dilakukan dapat diambil kesimpulan bahwa konsep diri memberikan pengaruh besar dan sangat positif secara langsung dari prestasi belajar. Sebagai contoh saja siswa yang merasa malu dengan perolehan hasil ulangan baik nilai ujian tengah semester dan ujian akhir semester yang rendah dari teman atau siswa lainnya, siswa ini 
mempunyai konsep diri yang tinggi untuk berubah agar tidak mendapatkan nilai rendah dilain waktu untuk ujian selanjutnya maka akan cenderung untuk tekun belajar guna mendapatkan keinginnya sehingga dapat meningkatkan prestasi hasil belajar matematikanya. Sedangkan bila sebaliknya siswa ini kurang atau lemah konsep dirinya dalam hal ini keinginan untuk memperoleh nilai matematika yang lebih baik ataupun tidak memiliki keinginan maju lebih baik lagi maka siswa akan cenderung malas untuk belajar matematika.

Sedangkan kemampuan untuk mengkonsep diri akan memberikan dampak secara langsung terhadap peningkatan kemampuan berpikir kritik didalam pembelajaran matematika misalnya keingintahuan individu atas permasalahan yang dihadapi seperti penyelesaian terhadap soal matematika yang diberikan dimana siswa ini menginginkan penyelesaian dengan rumus matematika yang menurut siswa tersebut mudah untuk dipahaminya dari berbagai alternatif pilihan rumus yang diberikan.

Dengan demikian terdapat pengaruh langsung yang signifikan kemampuan berpikir kritik terhadap konsep diri . hal ini ditunjukkan oleh angka koefisen jalur sebesar $=0.224$ lebih besar dari 0.05 dan hasil uji $-\mathrm{t}$ dimana nilai $\mathrm{t}$ hitung $=2.157>$ $\mathrm{t}_{\text {tabel }}=1.987$. besarnya pengaruh kemampuan berpikir kritik terhadap konsep diri adalah sama dengan $\mathrm{KD}=\mathrm{P}_{12}{ }^{2} \mathrm{X} 100 \%=0.224^{2}$ $\mathrm{X} 100 \%=5.01 \%$ sedangkan sisanya sebesar $94.99 \%$ dipengaruhi oleh faktor lainnya.

Berdasarkan uji penelitian survei, yakni apabila seseorang tersebut mampu mengkonsep dirinya atas permasalahan yang dihadapi maka secara langsung kemampuan berpikir kritik akan timbul sejalan dengan pencarian jawaban atau penyelesaian permasalahan yang dihadapi.

\section{SIMPULAN}

Simpulan dari hasil penelitian adalah: (1) Semakin baik kemampuan berpikir kritik yang dimiliki oleh siswa maka semakin baik pula prestasi belajarnya, (2) Adanya konsep diri yang positif dalam hal ini harga diri dan rasa percaya diri siswa untuk mempelajari matematika maka dapat meningkatkan prestasi belajar matematika, (3)Terdapat pengaruh langsung yang signifikan kemampuan berpikir kritik terhadap konsep diri, maka dapat diimplikasikan semakin baik kemampuan berpikir kritik dan konsep diri siswa maka semakin baik pula hasil prestasi belajar yang dicapai, (4) Lingkungan yang baik, didikan guru dan orangtua yang dapat membuat anak semakin percaya diri dan berkemampuan berpikir kritik merupakan bentuk dari motivasi yang bertujuan untuk peningkatan prestasi belajar matematika.

Saran dari hasil penelitian tersebut adalah (1) Bagi pendidik dan tenaga kependidikan khususnya para guru agar setiap kegiatan pembelajaran diharapkan diberikan permasalahan yang menarik sehingga para peserta didik tertantang untuk dapat meningkatkan kemampuan berpikir kritik sehingga kemampuan tersebut dapat meningkatkan prestasi belajar matematika menjadi lebih baik. (2) Bagi para orangtua, pendidik dan tenaga kependidikan diharapkan dapat terus meningkatkan pemberian motivasi dan arahan kedepan bagi para peserta didik sehingga peserta didik memiliki kemauan atau kemampuan mengkonsep diri menjadi lebih baik. (3) Perlu diadakan penelitian lanjutan untuk sampel dan variabel lebih besar, untuk mengetahui seberapa besar dampak kemampuan berpikir kritik dan konsep diri terhadap prestasi belajar matematika. 


\section{DAFTAR PUSTAKA}

[1] Sardiman, Interaksi dan Motivasi Belajar, Jakarta, PT Rineka Cipta, 2004.

[2] Nur Hidayah dan Adi Hatmoko, Landasan Sosial Budaya dan Psikologi Pendidikan: Terapannya di Kelas, Malang, Penerbit Gunung Samudera, cetakan 1, 201.

[3] Fisher, Alec, Berpikir Kritis sebuah Pengantar, Jakarta, Erlangga, 2009.

[4] Tim Pusat Studi Pancasila UGM, Membangun Kedaulatan Bangsa berdasarkan Nilai-nilai Pancasila: Pemberdayaan Masyarakat Dalam Kawasan Terluar, Terdepan dan Tertinggal (3T), Pusat Studi Pancasila Universitas Gadjah Mada, Cetakan Pertama, 2015.

[5] Arikunto, Suharsimi, Prosedure Penelitian Suatu Pendekatan Praktek, Jakarta, Rineka Cipta, 2006.

[6] Slameto, Belajar dan Faktor-faktor yang mempengaruhi, Jakarta, PT. Rineka Cipta, 2010. 